\title{
水稻の胡麻葉枯病䍜病に関する栄養生理的研究（予報）
}

\section{V. 夜温が水稻の生育及び無機成分の吸收に及注す影響}

\section{馬場 赳・高橋保夫・岩田岩保（農林省農業技術研究所）}

\author{
Studies on the nutrition of rice plant with reference to HelmiNthosporium \\ leaf spot (Preliminary report), \\ V. Growth and nutrient absorption as affected by night temperature. \\ Isamu BABA, Yasuo Takafasin and Iwaho Iwata \\ (National Institute of Agricultural Sciences)
}

暖地炕於ては夏季の気温殊伙登熟期間の夜温の高いことが水稻の秋落ちを助長しているといわれ，三原氏 （1947）は水稻の胡麻葉枯病も夜温の高い場合に多いことを実証した。元既に篗者等は第四報に於て夏季の水温 が適温より高い場合には無機成分の巾でも特に珪酸や加里の吸收が著しく減少することを明かにした。これら

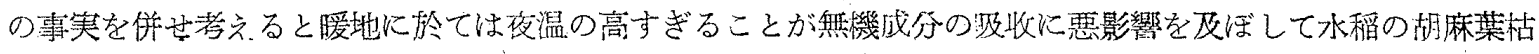
病や秋落らを助長しているのではないかと推測される。餢者等はこのような事寒の有無を験べる目的で登熟期

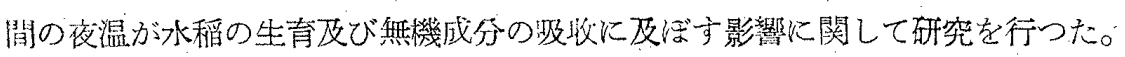

I 実験方法 㡺間は同一条件で育てた実験村料につき，夜間の気温を異にする高温区，小温区，低温区の 別を設けた。高温区では維物体を硝子室内没設けた，方５尺の硝子障子を組立てて造つた硝子箱内溜置し， 1〜2キロワットの電熱器で気温を高めた。ニクロム線からの輻射は上板を置いて遮つた。又気温が $30^{\circ} \mathrm{C}$ 以上飞舁ると自動的に電熱が止るように装置した。中温区では，高温区と同じく植物体を硝子室内に設けた組 立式硝子箱に留置し，加温は行わなかつた。何硝子箱内の換気を息くするために四面の硝子障子と土面との間 に 5 分及び四面の硝子障子と天井の障子との間に約 2 3 分の傹間を設けた。低温区では夜間植物体を戸外飞

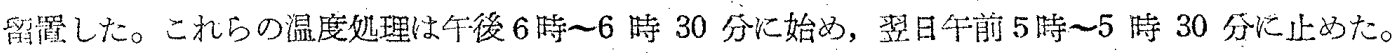

II 実験結果 第一実駼 7 月 8 日移植し 2.5 万分の 1 反深さ 1 尺の鉢で普通に土㜔栽培した水稻農林 22 号につき出穂期以後の1カ月間（9 月 5 日〜10月 5 日）前述の㛎き夜温を異にする区別を設けた。1区

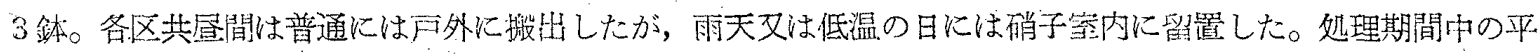
均気温は最高気温は $27.6^{\circ} \mathrm{C}$ (昼間), 夜間の最低気温は高温区は $24.5^{\circ} \mathrm{C}$, 中温区は $20.5^{\circ} \mathrm{C}$, 低温区は 15.7

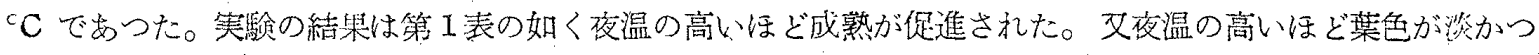

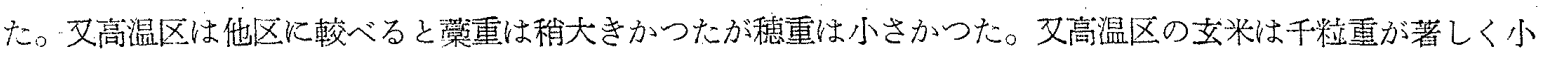
さく品質も秀つていた。即ち，中温区，低温区では粒の色沢倘色であつたが，高温区では鈍色で腹白が多かつ た。

第 1 表，夜温が水稻の生有，收量及び無㙨成分含量に及佂す影響

Table. 1. Growth, yield and nutrient content as affected by night temperature

\begin{tabular}{|c|c|c|c|c|c|c|c|c|c|c|c|}
\hline \multirow{2}{*}{$\begin{array}{l}\text { 区 别 } \\
\text { plot }\end{array}$} & \multirow{2}{*}{\begin{tabular}{|c|} 
成熟期 \\
Dates \\
of \\
ripening
\end{tabular}} & \multirow{2}{*}{\begin{tabular}{|c|} 
工株穗重 \\
Weight \\
of \\
panicles
\end{tabular}} & \multirow{2}{*}{$\begin{array}{l}\text { 1 株譡重 } \\
\text { Weight } \\
\text { of } \\
\text { straw } \\
\end{array}$} & \multirow{2}{*}{$\begin{array}{c}1 \text { 株方将重 } \\
\text { Weight of } \\
\text { grains }\end{array}$} & \multirow{2}{*}{$\begin{array}{c}\mathrm{x} \text { 米千粒重 } \\
\mathrm{Wt} \text {. of } \\
1,000 \\
\text { grains }\end{array}$} & \multirow{2}{*}{$\begin{array}{l}1 \text { 株胡麻葉 } \\
\text { 枯病㑢 No. } \\
\text { of lesion }\end{array}$} & \multicolumn{5}{|c|}{$\begin{array}{l}\text { 荎葉中の量 }(\%) \text { Percentage } \\
\text { contents in stems and leaves }\end{array}$} \\
\hline & & & & & & & $\mathrm{N}$ & $\mathrm{P}_{2} \mathrm{O}_{5}$ & $\mathrm{~K}_{2} \mathrm{O}$ & $\mathrm{SiO}_{2}$ & ก \\
\hline & & & 560 & & 18 & & 0. & & & 3 & \\
\hline & X. 25 & & & & & & 0 & 0.274 & 1.58 & 3.33 & 0.0 \\
\hline 昷 L.T. & X. 30 & 47.2 & 55.3 & & 21.40 & & - & & - & - & \\
\hline
\end{tabular}

Average temperature during the treatment : Maximum Temperature $-27.6^{\circ} \mathrm{C}$ (all plots) Minimum temperature (at right) $-\mathrm{H}$. T. $24.5^{\circ} \mathrm{C}, \mathrm{M}$. T. $20.5^{\circ} \mathrm{C}, \quad$ L. T. $15.7^{\circ} \mathrm{C}$

* 昭和 27 年 2 月 23 日 第 94 回講崚会に於て発表 日本作物学会紀事 第 21 巻 第 3 4 是 


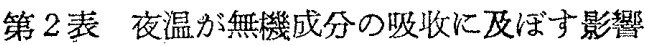

Table. 2. Nutrient absorption as affected by night temperature

\begin{tabular}{|c|c|c|c|c|c|c|c|}
\hline \multirow{2}{*}{ 区 ${ }^{\text {plot }}$} & \multicolumn{5}{|c|}{$\begin{array}{c}\text { 忣收 量 } \text { क 割 } \\
\text { Amounts absorbed }(\%)\end{array}$} & \multicolumn{2}{|c|}{$\begin{array}{l}\text { 吸收量の地率 } \\
\text { Ratio amounts } \\
\text { absorbed }\end{array}$} \\
\hline & $\mathrm{NH}_{3}-\mathrm{N}$ & $\mathrm{P}_{2} \mathrm{O}_{5}$ & $\mathrm{~K}_{2} \mathrm{O}$ & $\mathrm{SiO}_{2}$ & $\mathrm{MnO}$ & $\mathrm{K}_{2} \mathrm{O} / \mathrm{N}$ & $\mathrm{SiO} / \mathrm{N}$ \\
\hline 高温 H.T. & 85 & 96 & 58 & 81 & 86 & 0.31 & 8.25 \\
\hline 中温 H.T. & 00 & 100 & 100 & 100 & 100 & 0.46 & 8.58 \\
\hline 低温 L.T。 & 98 & 104 & 87 & 93 & 102 & 0.41 & 8.10 \\
\hline
\end{tabular}

Maximum temperature (all plots) $-34^{\circ} \mathrm{C}$; Minimum temperature (at night) - H.T. $27 .{ }^{\circ} \mathrm{C}$, M.T. $22^{\circ} \mathrm{C}$, L.T. $17^{\circ} \mathrm{C}$
湖麻葉枯病の䍜病も高温 区が中温区より稍大であ つた。又茥葉を分析した 結果高温区は中温区に較 べて加里, 珪酸の含量が 低く，会量上に於ける $\mathrm{K}_{2} \mathrm{O} / \mathrm{N}$ 及び $\mathrm{SiO}_{2} / \mathrm{N}$ が 小さかつた。

\section{第二実験 2.5 立入の} 三角フラスコに水耕培養

した水稻愛知旭につき 9 月 14 日 10 時〜15 日 10 時の期間だけ前述の如き方法で夜温を異にする区別を設 けて 24 時間中に於ける無機成分の吸收をしらべた。何 9 月 14 日は崇天で気温が低かつたので昼間る各区の 稲を組立式硝子箱中に入れて加温した。㡺間の最高気温は $34^{\circ} \mathrm{C}$, 夜温の最低気温は高温区は $27^{\circ} \mathrm{C}$, 中温区 は $22^{\circ} \mathrm{C}$ ，低温区は $17^{\circ} \mathrm{C}$ であつた。水耕液を分析して 24 時間中に於ける無機成分の吸收量を求め，各無機 成分につき中温区の吸收量に対する他区の吸收量の百分率を求めた結果は第 2 表の如くである。同表から高温 区及び低温区は中温区汇較べると無機成分の吸收は $\mathrm{K}_{2} \mathrm{O}>\mathrm{SiO}_{2}>\mathrm{NH}_{3}-\mathrm{N}>\mathrm{MnO}>\mathrm{P}_{2} \mathrm{O}_{5}$ の順汇娍退し，吸收 量に於ける $\mathrm{K}_{2} \mathrm{O} / \mathrm{N}$ 及び $\mathrm{SiO}_{2} / \mathrm{N}$ す小さいことが諮められる。

III 考 察 第二実験に於て, 夜温を高低せしめた場合の無機成分の吸收の減退程度の順序は, 筆者等の第 而報に於汁る水温を適温上り高低せしめた場合に於ける無機成分の吸收の減退程度の順序と凡そ一致している ことが垫められる。徒つて水温を適温より高低せしめた場合と同じく，夜温を適温より高低せしめた場命にも 根の正常な好気的物質代謝が抑制せられて無㙨成分の吸收がイオッの水和度の順序に彷つて娍退するこそにな ると考えられる。このような事実から，第一実験に於て高温区が中温区に較べて蓝葉の加里と珪酸の含量が小 さく，胡麻葉枯病の䍜病が多いのも，水和度の大きい加里や珪酸の吸收が著しく阻害されたためであろう。こ のような事実から暖地伦於ける水稻の湖麻某枯病度び秋落の激発に対しては, 高夜温によつて加里及び珪酸等 の無機成分の吸收吕著しく減退することが一部関係していると考えられる。本研究に当り激励と指導を頂いた 盛永博士及び林武氏に梁葚なる謝意を表する。

\section{Résumé}

To make clear whether the serious occurrence of Helminthosporium leaf spot or "Akiochi" in the south-western parts of Japan is accelerated by the abnomal plant nutrition due to high night temperature of air or not, two experiments were carried out in 1951: in one experiment influence of night temperature treatment for a month after heading upon the growth and nutrition of rice plant was studied, and in another experiment quantities of nutrients absorbed by rice during 24 hours after $10 \mathrm{a}$. $\mathrm{m}$. September 14 were determined under different night temperature conditions. The results of the experiments are as follows:-

(1) High night temperature treatment for a month after heading speeded up the ripening of plant and also retarded the normal development of grains, resulting in the loss of yield. The treatment also diminished the percentage contents of potassium and silica in stems and leaves, and increased the susceptibility to Helminthosporium leaf spot (Table 1).

(2) Both high and low night temperature of air reduced the absorption of nutrients in the order $\mathrm{K}_{2} \mathrm{O}>\mathrm{SiO}_{2}>\mathrm{NH}_{3}-\mathrm{N}>\mathrm{MnO}>\mathrm{P}_{2} \mathrm{O}_{5}$ (Table 2). Therefore it is suggested that both supra-optimal and low night temperature retard the normal aerobic metabolism of root and cause the reduction of ions absorption according to the order of hydration.

(3) From these results the serious occurrence of Helminthosporium leaf spot or "Akiochi" in the south-western parts of Japan may be attributed in part to the absorption inhibition of some nutrients such as potassium and silica caused by high night temperature. 